\title{
THE EFFECT OF THE SELECTED REMEDIATION MEDIUM ON THE CADMIUM BIOAVAILABILITY IN THE SELECTED ECOSYSTEM IN THE SOUTHWESTERN LOCALITY OF SLOVAKIA
}

\author{
JANA URMINSKÁ ${ }^{1}$, TOMÁŠ TÓTH ${ }^{2}$, RENÁTA BENDA PROKEINOVÁ ${ }^{3}$, PETER ONDRIŠÍK ${ }^{1}$
}

${ }^{1}$ Department of Environmentalism and Zoology, Faculty of Agrobiology and Food Resources, Slovak University of Agriculture in Nitra, Tr. A. Hlinku 2, 94976 Nitra, Slovak Republic; e-mail: jana.urminska@uniag.sk, peter. ondrisik@uniag.sk

${ }^{2}$ Department of Chemistry, Faculty of Biotechnology and Food Sciences, Slovak University of Agriculture in Nitra, Tr. A. Hlinku 2, 94976 Nitra, Slovak Republic; e-mail: tomas.toth@uniag.sk

${ }^{3}$ Department of Statistics and Operations Research, Faculty of Economics and Management, Slovak University of Agriculture in Nitra, Tr. A. Hlinku 2, 94976 Nitra, Slovak Republic; e-mail: renata.prokeinova@uniag.sk

\begin{abstract}
Urminská J., Tóth T., Benda Prokeinová R., Ondrišík P.: The effect of the selected remediation medium on the cadmium bioavailability in the selected ecosystem in the Southwestern locality of Slovakia. Ekológia (Bratislava), Vol. 38, No. 3, p. 214-224, 2019.

Soil is a sensitive ecological factor. Biodegradable materials from the environment can also be used to deal with serious ecological problems. Soil affecting by remediation medium - garden compost - was analysed for toxic cadmium (Cd) in terms of environmental protection. The objective of this research was to analyse soil and compost at foothill locality of the Tribeč Mountains (Southwestern Slovakia) in the years 2015-2017 to determine Cd contents in soil and compost, $\mathrm{pH}$ and to assess Cd bioavailability. The analyses were carried out using the Atomic Absorption Spectrometry with sevenstep Selective Sequential Extraction methods. The results obtained were evaluated statistically using the SAS 9.4 software method by Spearman's correlation coefficient. The results showed that Cd contents in soil had reached $2.96 \mathrm{mg} \mathrm{kg}^{-1}$ and soil with compost (the ratio $1: 1$ ) $2.71 \mathrm{mg} \mathrm{kg}^{-1}$ dry matter. Cd contents in the soil exceeded maximum allowed limit of $196 \%$. And deceased by $25 \%$ after adding compost. The $\mathrm{pH}$ in soil with compost varied from 6.78 to 7.98 . The $\mathrm{pH}$ prevented the mobility of Cd about $8.3 \%$ in average. Statistical dependence was high, which was demonstrated for relationship between $\mathrm{Cd}$ in soil, $\mathrm{pH}$ and compost. Available $\mathrm{Cd}$ forms in soil were $53.3 \%$ and soil with compost were $45 \%$ in average. The garden compost as a remediation medium reduced Cd bioavailability.
\end{abstract}

Key words: fractionation, garden compost, high risk element, nature protection, seven-step selective sequential extraction.

\section{Introduction}

As environmental pollution is now a global phenomenon, the territory of the Slovak Republic is also not spared from this. At present, the ecological health quality is also affected by anthropogenic activities (Šimanský, 2015; Fazekaš et al., 2018). Growing of healthy foods is a 
priority for ecological awareness (El Rasafi et al., 2016). We still have to deal with increased and accessible forms of risk elements. It is justified to address the restriction of availability of toxic elements into organisms by means of easy to produce and economy remediation media. The agricultural production strives for sustainable management, which requires a lot of effort on the part of all those involved when it comes to maintaining a balance between income and nutrient expenditure in soil. Insufficient application of organic fertilizers leads to a gradual degradation of organic matter in soil, which contributes to the reduction of soil fertility and increase in risk of the toxic elements into soils, into all ecosystems (Fazekašová et al., 2013). Improper interventions on soil lead to gradual soil degradation, which reduce soil fertility and increase high risk of toxic elements in soil (Morais et al., 2012; Ying et al., 2018). In this case, the current low-utilizable biodegradable organic substances play an important role. In agricultural garden practice, when optimizing plant nutrition, pesticides are used in the long run; industrial fertilizers bring benefits but also dangerous risks. From the point of view of the demand of quality foodstuffs, which are not influenced by dangerous substances, cultivation with the use of alternative media is preferred in growing conditions too. Such a substance is a compost as a complementary alternative to plant nutrition, as well as a remediation medium that affects the bioavailability of risk elements in soil ecosystem (Belyuchenko, 2016; Khan et al., 2017). Composting technology is a naturally controlled biochemical and biological process, in which microorganisms and organisms decompose the substrates used for humus substances that are suitable for soil remediation. At present, when using garden compost as a remediation factor, it is necessary to take into account especially its quality. Important parameters are included in the concentration and the bioavailability of chemicals and potentially a soil exchange reaction. Composting is an aerobic process where biodegradable organic waste is converted to an organic-mineral fertilizer and a valuable remediation medium too (Belyuchenko, 2016; de O. Pinto et al., 2016; Khan et al., 2017). For the optimal course of biodegradation, it is important to formulate input substrates, which must provide the required parameters in terms of physical, chemical, biochemical, biological and the production process must be observed. Composting of biodegradable organic substances represents a technology of natural remediation and recycling based on natural, economic principles (de O. Pinto et al., 2016). Each component of the environment has a wide variety of chemical elements. At present, due to an increase in anthropogenic activities, there is a disproportionate increase in the concentration of risk elements in the environment (Morais et al., 2012; Ying et al., 2018). Such a highly toxic element is ubiquitous cadmium (Cd) (Liu et al., 2016; Shi-Wei et al., 2016; Peng et al., 2017). This work is focused on toxic Cd, which belongs to the element with a high risk potential for soil, plants and human health (Meharg et al., 2013; Das et al., 2014; Shi-Wei et al., 2016; Borgulat et al., 2018) and is focused on remediation medium - garden compost, which is usable in agricultural practices and has the potential to reduce the availability of toxic elements to the environment. It needs to be used more in the present practice. The main objectives of this paper were: to determine the Cd concentrations in topsoil and topsoil affected by remediation medium - garden compost (the ratio 1:1, the best scientifically proven division according to the valid agrochemical practice) by Atomic Absorption Spectrometry method during the long scientifically appropriate time; to determine potentially a soil exchange reaction in topsoil and topsoil affecting the garden 
compost as a key parameter in the assessment of mobility and bioavailability of risk elements in the environment; to do a detailed seven-steps fractionation of $\mathrm{Cd}$ in these accumulation mediums; to evaluate the statistical significance of dependencies of monitored parameters using by SAS Software; to find whether real garden compost as a remediation medium affects the bioavailability of Cd over a long time frame.

\section{Material and methods}

Agricultural land as a garden type is still not sufficiently explored for the contents of risk elements, while they are playing an important role in ecosystems.

\section{Study area and creation of the garden compost}

The monitored area was selected from the growing area at the foothills locality of the Tribeč Mountain, Southwestern of the Slovak Republic $\left(48^{\circ} 20^{\prime} 15^{\prime \prime} \mathrm{N}, 18^{\circ} 06^{\prime} 30^{\prime \prime} \mathrm{E}, 236 \mathrm{~m}\right.$ above sea level) in the years 2015-2017. Remediation medium - garden compost - was created on the basis of agrochemical practice and valid legislation of the Slovak Republic (Act No. 79/2015 Coll. of Laws) for the production and processing of biodegradable organic waste materials. Ingredient materials for compost as a remediation medium were: mowed grass, biowaste from households, vegetable waste, weeds, sawdust, straws, dry grass, shrubs, barks, leaves and needles tree, soil (Rendzic Leptosol), slaked lime (The materials used were applied in the exact percentage, the compost area was $4 \mathrm{~m}^{2}$, the maximum height of one ingredient was up to $10 \mathrm{~cm}$, the moisture, grain size and above all, process hygiene were maintained. The maximum composting height was $1.20 \mathrm{~m}$ ). The composting process was put through the stages of decomposition, transformation, synthesis, stabilization and maturation processes.

\section{Topsoil, remediation medium - garden compost and data analyses}

The methodology for sampling the soil was governed by the valid the Slovak Republic legislation on agricultural land (Decree No. 59/2013 Coll.; NAFC, 2019). Sampling of soil was realized regularly at monthly intervals and was monitored over the years 2015-2017. It was carried out by a drilling probe placed in the centre of a circular shape with a radius of $10 \mathrm{~m}$, the depth of $20 \mathrm{~cm}$, and in addition, the sampling of 5 separate samples weighing $0.5 \mathrm{~kg}$ were randomly collected from the surface soil horizon from the sites for chemical analysis (NAFC, 2019). The samples were homogenized and dried at $40^{\circ} \mathrm{C}$ for 48 hours. Subsequently, they were ground with a VEB ThurmZG1 (an instrument VEB Elektromotorenwerke Kreis Zwickau DDR/GDR) soil grinder to a fine grain $(2.0 \mathrm{~mm})$. A potential soil exchange reaction soil exchange reaction was determined in aqueous extracts of $1 \mathrm{~mol} \mathrm{dm}^{-3} \mathrm{KCl}$, according to the soil methodology (Fiala et al., 1999, an instrument InfolabMulti - WTW company). Analysis of leachate samples were carried out using aqua regia $\left(\mathrm{HNO}_{3}+\mathrm{HCl} 1: 3\right)$ using the Atomic Absorption Spectrometry method in an acetylene-air flame on a Varian AA240FS instrument (Fast Sequential Absorption Spectrometer - Amedis company, CA). The Selective Sequential Extraction method was used for individual Cd fractions in soil and soil mixed with garden compost as a remediation medium (the ratio 1:1). Bioavailability was monitored according to the seven-step Selective Sequential Extraction methodology (detailed methodology in the Ziehen, Brümmer, 1991). The fractions analysed included (Ziehen, Brümmer, 1991):

- Label F1, representing a mobile bioavailable element form; extractant $1 \mathrm{~mol} \mathrm{dm}^{-3} \mathrm{NH}_{4} \mathrm{NO}_{3}$,

- Label F2, a lightly permissible form of element; extractant $1 \mathrm{~mol} \mathrm{~cm}^{-3} \mathrm{C}_{2} \mathrm{H}_{7} \mathrm{NO}_{2} \mathrm{pH} 6.0$,

- Label F3, is a part of the element bound to Mn-oxides; extractant $0.1 \mathrm{~mol} \mathrm{dm}^{-3} \mathrm{NH}_{2} \mathrm{OH} \cdot \mathrm{HCl}+1 \mathrm{~mol} \mathrm{dm}^{-3}$ $\mathrm{C}_{2} \mathrm{H}_{3} \mathrm{NaO}_{2} \mathrm{pH} 6.0$,

- Label F4, which is a part of the element bound to organic matter; extractant $0.025 \mathrm{~mol} \mathrm{dm}^{-3} \mathrm{NH}_{4}-\mathrm{EDTA} \mathrm{pH}$ 4.6,

- Lebel F5, which is a part of the element bound to amorphous of Fe-oxides; extractant $1 \mathrm{~mol} \mathrm{dm}^{-3} \mathrm{C}_{2} \mathrm{H}_{7} \mathrm{NO}_{2}$ $\mathrm{pH} 4.6$,

- $\quad$ Label F6, which is a part of the element bound to crystalline Fe-oxides; extractant $0.1 \mathrm{~mol} \mathrm{dm}^{-3} \mathrm{C}_{6} \mathrm{H}_{8} \mathrm{O}_{6}+0.2$ mol dm${ }^{-3} \mathrm{NH}_{4}$-oxalate $\mathrm{pH} 3$,

- Label F7, which is a part of residual element form; extractant $65 \% \mathrm{HNO}_{3}+72 \% \mathrm{HClO}_{4}$. 
Overall, the weather conditions during the complete research period did not disrupt the course of the research (Tables 1,2). The observed locality of Southwestern Slovakia belongs to a warm and slightly dry climate region with a good level of diversity in its ecosystems.

T a b l e 1 . The average monthly temperatures $\left({ }^{\circ} \mathrm{C}\right)$ in the years 2015-2017.

\begin{tabular}{|c|c|c|c|}
\hline A months & Year 2015 & Year 2016 & Year 2017 \\
\hline I. & 1.6 & -0.6 & -9.1 \\
\hline II. & 1.2 & 5.5 & 0.1 \\
\hline III. & 6.3 & 4.3 & 8.7 \\
\hline IV. & 10.4 & 9.3 & 9.7 \\
\hline V. & 15.1 & 15.0 & 16.6 \\
\hline VI. & 19.9 & 20.3 & 21.2 \\
\hline VII. & 23.6 & 21.4 & 21.7 \\
\hline VIII. & 23.5 & 19.5 & 22.4 \\
\hline IX. & 17.5 & 17.5 & 14.6 \\
\hline X. & 10.5 & 9.4 & 10.6 \\
\hline XI. & 6.0 & 3.8 & 5.0 \\
\hline XII. & 2.6 & -2.7 & 1.6 \\
\hline & & & \\
\hline
\end{tabular}

T a b l e 2. Total monthly precipitation $(\mathrm{mm})$ in the years 2015-2017.

\begin{tabular}{|c|c|c|c|}
\hline A months & Year 2015 & Year 2016 & Year 2017 \\
\hline I. & 52.0 & 28.6 & 12.8 \\
\hline II. & 28.9 & 78.3 & 26.4 \\
\hline III. & 35.4 & 32.4 & 9.9 \\
\hline IV. & 25.0 & 24.8 & 39.5 \\
\hline V. & 69.5 & 91.3 & 14.0 \\
\hline VI. & 10.2 & 14.4 & 26.1 \\
\hline VII. & 17.2 & 134.7 & 60.0 \\
\hline VIII. & 57.7 & 35.0 & 23.2 \\
\hline IX. & 33.2 & 36.9 & 93.0 \\
\hline X. & 54.8 & 69.3 & 50.2 \\
\hline XI. & 24.2 & 35.3 & 21.8 \\
\hline XII. & 10.1 & 14.2 & 45.2 \\
\hline
\end{tabular}

The results obtained were evaluated statistically using SAS 9.4 (North California USA) (Benda Prokeinová, 2014) method by the Spearman's correlation coefficient (Stehlíková, 1999). SAS provided all the activities related to performing risk analysis and selecting control samples. Spearman's correlation was used to check the relationship between selected observed parameters in soil and remediation medium.

\section{Results and discussion}

Each component of the environment has a wide variety of chemical elements. These also include heavy metals. Issues in their study include several important reasons: they are relatively expanded in environmental compartments, accumulate and form non-degradable waste; some are physiologically important for ecosystems (Poláková et al., 2011; Šillerová et al., 2011, 2012; Urminská et al., 2013); at high concentrations, they cause undesirable effects in biogeochemical cycle, and thus, have a direct relationship with agricultural production and human health (Morais et al., 2012; Meharg et al., 2013; Onistratenko et al., 2016; Peng et al., 2017). Their toxic effect may be manifested after an over concentration in the ecosystems, depending particularly on the contents of mobile and mobilizable forms (Bencko et al., 1995; Khun et al., 2008). The results showed that the proportion of fractions in the topsoil in the year 2015 were in the order: F7 > F2 > F3 > F6 > F1 > F5 > F4; in topsoil in the year 2016, these were in a little different order: F7 $>$ F1 $>$ F2 $>$ F3 $>$ F6 $>$ F4 $>$ F5; in the topsoil in the year 2017, these, were in the order: F7 > F2 > F1 > F3 > F6 > F4 > F5; in the topsoil affected by remediation medium - garden compost (the ratio 1:1) in the year 2015, these were in the order: F7 > F2 > F3 > F6 > F1 > F4 > F5; in the year 2016, these were in the order: F7 $>$ F1 > F3 $>$ F2 $>$ F6 $>$ F4 $>$ F5; and in the year 2017, these were in the order: F7 $>$ F1 $>$ F2 $>$ F3 $>$ F4 $>$ F6 $>$ F5 (Fig. 1). 


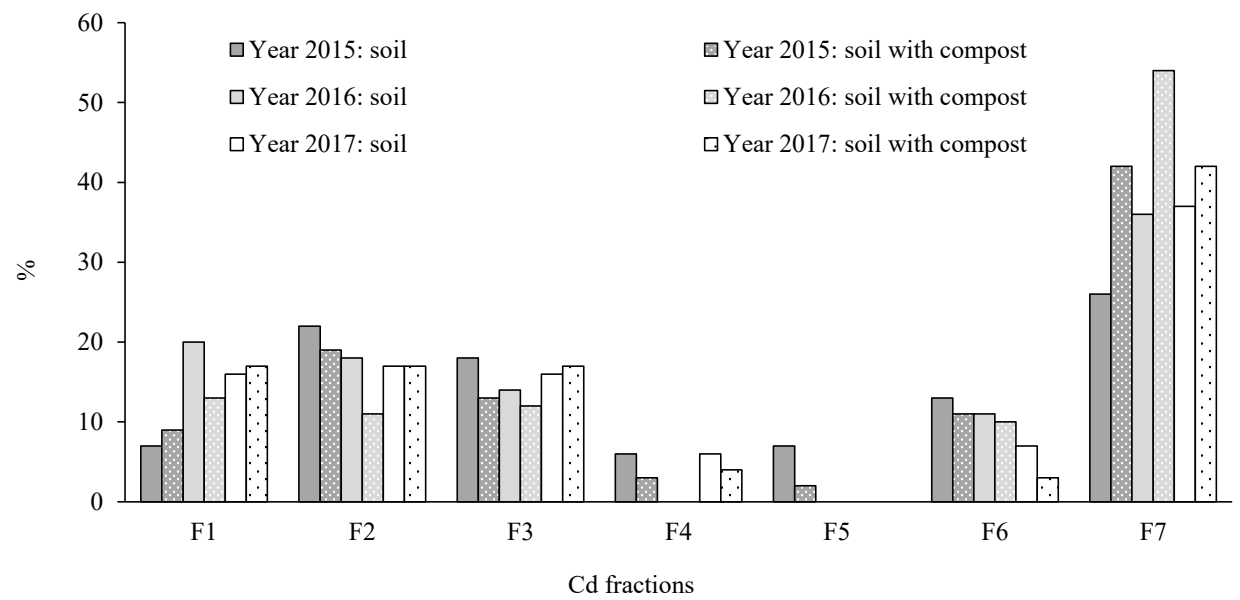

Fig. 1. Determination of cadmium for fractions in soil and soil with compost (the ratio 1:1) in the years 2015-2017.

The residual fraction F7 especially dominated, which is acceptable for the ecosystem. But was followed by bioavailable leachable fractions F1, F2. This fact confirm the findings of Makovníková et al. (2006), Khun et al. (2008), Liu et al. (2008) and Boriová et al. (2015). In our research, it was found that the bioavailable Cd forms (from the 1st to 4 th fractions) reached $53 \%$ in the year $2015,52 \%$ in the year 2016 , and in the year 2017 , up to $55 \%$, of which, the most bioavailable form F1 and F2 in the year 2015 up to 29\%, in the year 2016 up to 38\% and in the year 2017 up to $33 \%$. Bioavailable forms for organisms often exceed more than $50 \%$ (Liu et al., 2008). It was found that the bioavailability of $\mathrm{Cd}$ from soil for crops after the addition of garden compost significantly decreased by approximately $16 \%$ for accessible fractions F1 to F4. For the most bioavailable fractions, F1 and F2 were found to vary from 1 to $14 \%$. It was shown that creation of compost positively affected the bioavailability of Cd over the research period under review from the soil for growing crops (de O. Pinto et al., 2016). It significantly reduced Cd availability. The Selective Sequential Extractions based on predefined procedures provided interesting information on bioavailability, and consequently, the risk of environmental contamination (Makovníková et al., 2006; Boriová et al., 2015). In the fractionation carried out by the Selective Sequential Extraction, the individual solid phases are elucidated from the accumulation media together with the elucidation of the elements associated with these phases (Cuske et al., 2017). Methods that use various extraction agents to determine the bioavailability of an element are useful in assessing real ecological risks (Antonkiewicz, Pełka, 2014; Boriová et al., 2015; Belyuchenko et al., 2016). Significant statistical correlations were found between mobile and potentially mobile heavy metal and organic amendments (Cuske et al., 2016; Khan et al., 2017) and pH too. The Cd contents, mean and standard deviation of the monitored parameters ( $\mathrm{mg} \mathrm{kg}^{-1}$ of dry soil) in the years $2015-2017$ are documented in Table 3. The statistically highly significant correlation coefficients between the selected important parameters in the years 2015-2017 are documented in Table 4. 
$\mathrm{T} \mathrm{a} \mathrm{b} \mathrm{le} \mathrm{3.} \mathrm{Variance} \mathrm{analyses} \mathrm{of} \mathrm{Cd} \mathrm{contents} \mathrm{(} \mathrm{mg} \mathrm{kg}^{-1}$ of dry matter) in soil and soil with compost (the ratio 1:1), $\mathrm{pH}$ in soil and soil with compost (the ratio 1:1) in the years 2015-2017 $(n=12)$.

\begin{tabular}{|l|l|c|c|c|c|c|}
\hline Years & Analysed parts & Mean & Std. Dev. & Sum & Min & Max \\
\hline Year 2015 & Cd soil & 2.45250 & 0.33374 & 29.43 & 1.98 & 2.96 \\
\hline & pH soil & 6.27250 & 0.16510 & 75.27 & 5.98 & 6.51 \\
\hline & Cd soil + compost & 2.33667 & 0.27424 & 28.04 & 1.89 & 2.71 \\
\hline & pH soil + compost & 7.69083 & 0.31713 & 92.29 & 6.78 & 7.98 \\
\hline Year 2016 & Cd soil & 2.51000 & 0.33823 & 30.12 & 1.78 & 2.93 \\
\hline & pH soil & 6.27833 & 0.21854 & 75.34 & 5.97 & 6.83 \\
\hline & Cd soil + compost & 2.34500 & 0.25465 & 28.14 & 1.95 & 2.68 \\
\hline & pH soil + compost & 7.67667 & 0.15245 & 92.12 & 7.31 & 7.87 \\
\hline & Cd soil & 2.49419 & 0.32609 & 29.93 & 1.82 & 2.89 \\
\hline & pH soil & 6.14167 & 0.26683 & 73.70 & 5.74 & 6.56 \\
\hline & Cd soil + compost & 2.37000 & 0.21076 & 28.44 & 2.04 & 2.68 \\
\hline & pH soil + compost & 7.63750 & 0.20623 & 91.65 & 7.20 & 7.97 \\
\hline
\end{tabular}

$\mathrm{T}$ a b l e 4 . The statistically highly significant correlation coefficients between the selected important parameters in the years 2015-2017.

\begin{tabular}{|l|c|c|c|c|c|}
\hline $\begin{array}{l}\text { Relationship } \\
\text { parameters }\end{array}$ & $\begin{array}{c}\text { Cd S } \\
\mathbf{2 0 1 5}\end{array}$ & $\begin{array}{c}\text { Cd S } \\
\mathbf{2 0 1 6}\end{array}$ & $\begin{array}{c}\text { Cd S } \\
\mathbf{2 0 1 7}\end{array}$ & $\begin{array}{c}\text { Cd S + C } \\
\mathbf{2 0 1 5}\end{array}$ & $\begin{array}{c}\text { Cd S + C } \\
\mathbf{2 0 1 6}\end{array}$ \\
\hline Cd S 2016 & $0.92542^{* * *}$ & & & & \\
\hline Cd S 2017 & $0.92711^{* * *}$ & $0.96989^{* * *}$ & & & \\
\hline Cd S + C 2015 & $0.71983^{* *}$ & $\mathrm{~ns}$ & $\mathrm{~ns}$ & & \\
\hline Cd S + C 2016 & $\mathrm{ns}$ & $0.73557^{\star *}$ & $\mathrm{~ns}$ & $0.97127^{* * *}$ & \\
\hline Cd S + C 2017 & $\mathrm{ns}$ & $\mathrm{ns}$ & $0.86483^{* * *}$ & $0.91779^{* * *}$ & $0.92995^{* * *}$ \\
\hline pH/KCl S 2016 & $\mathrm{ns}$ & $-0.71000^{* *}$ & $\mathrm{~ns}$ & $\mathrm{~ns}$ & $\mathrm{~ns}$ \\
\hline pH/KCl S 2017 & $\mathrm{ns}$ & $\mathrm{ns}$ & $-0.57724^{*}$ & $\mathrm{~ns}$ & $\mathrm{~ns}$ \\
\hline pH/KCl S + C 2015 & $\mathrm{ns}$ & $\mathrm{ns}$ & $\mathrm{ns}$ & $0.81161^{\star *}$ & $\mathrm{~ns}$ \\
\hline pH/KCl S + C 2016 & $\mathrm{ns}$ & $\mathrm{ns}$ & $\mathrm{ns}$ & $\mathrm{ns}$ & $0.70110^{* *}$ \\
\hline
\end{tabular}

Notes: significance level $\mathrm{p}_{\text {value }}<0.05^{\star} ; \mathrm{p}_{\text {value }}<0.01^{\star *} ; \mathrm{p}_{\text {value }}<0.001^{\star * *} ;$ ns - not significantly; $\mathrm{S}$ - soil; $\mathrm{S}+\mathrm{C}-$ mixed soil + compost (the ratio 1:1).

Statistical dependence of the observed parameters was demonstrated for the relationship between $\mathrm{Cd}$ in soil : Cd in soil + compost, $\mathrm{Cd}$ in soil : $\mathrm{pH}$ in soil, $\mathrm{Cd}$ in soil + compost : $\mathrm{pH}$ in soil + compost. Especially high significance was determined for soil and garden compost, which correspondents to the long-term scientific patterns (de O. Pinto et al., 2016; Khan et al., 2017). Interesting data was found on the relationship between Cd contents in soil and $\mathrm{pH} /$ $\mathrm{KCl}$ in soil during the years - Spearman's correlation coefficient confirmed a negative correlation. It has been shown that the $\mathrm{Cd}$ contents is $\mathrm{pH}$ dependent, and where the $\mathrm{Cd}$ contents increases, there is a decrease in $\mathrm{pH}$. For the relationship between Cd contents in soil during the years, the Spearman's correlation coefficients confirmed a positive correlation. This fact represents that $\mathrm{Cd}$ contents during the years were dependent. A similar fact applies to the 
relationship - observed years and soil affected by compost. A very important correlation was found between $\mathrm{Cd}$ contents in soil and Cd contents in soil affected by compost. Spearman's coefficients are high and dependencies are positive. Cd contents in soil is significantly positively affected by the addition of compost. Cd contents in soil varied from $1.78 \mathrm{mg} \mathrm{kg}^{-1}$ to 2.96 $\mathrm{mg} \mathrm{kg}^{-1}$ dry matter and soil affecting by garden compost (relationship 1:1) from $1.89 \mathrm{mg} \mathrm{kg}^{-1}$ to $2.71 \mathrm{mg} \mathrm{kg}^{-1}$ dry matter. Cd contents in soil exceeded the limit up to $78 \%$ (in April in the year 2016) - 196\% (in December in the year 2015) (limit for Cd in soil is $1.0 \mathrm{mg} \mathrm{kg}^{-1}$ of dry matter, Decree No. 59/2013 Coll.), in soil with garden compost up to 89\% (in March in the year 2015) - 171\% (in October in the year 2015) (Fig. 2).

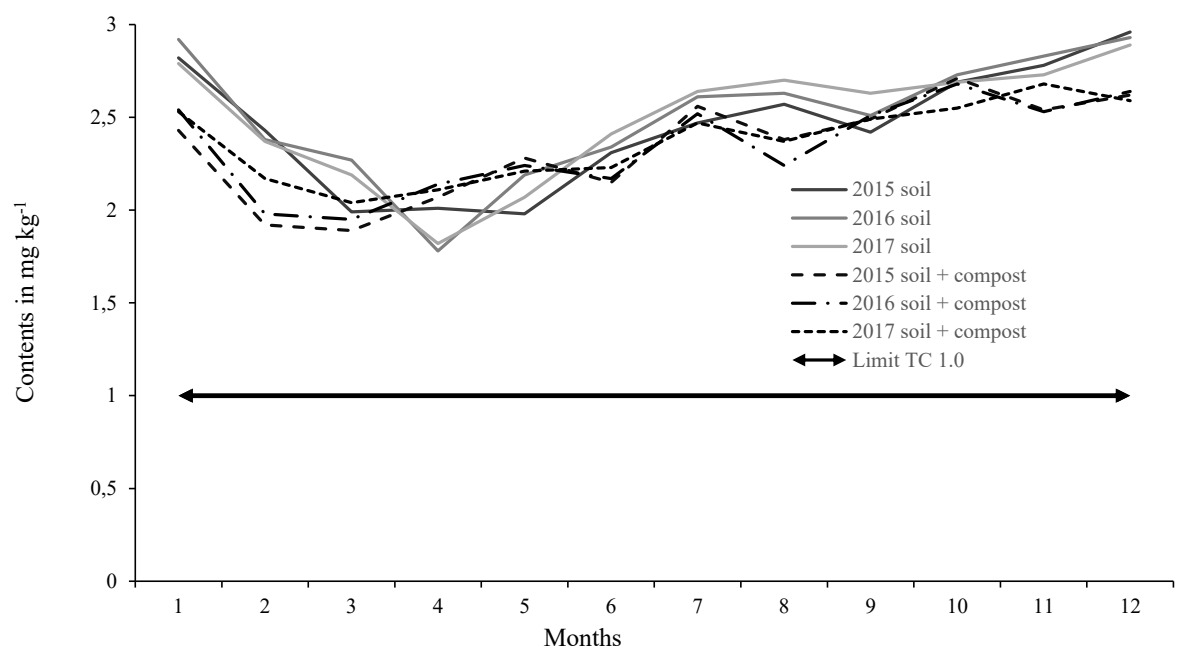

Fig. 2. Cd contents ( $\mathrm{mg} \mathrm{kg}^{-1}$ of dry matter) in soil and Cd contents in soil + compost (the ratio 1:1) in the years 2015-2017.

Notes: 1 January, 2 February, 3 March, 4 April, 5 May, 6 June, 7 July, 8 August, 9 September,10 October, 11 November, 12 December.

That contents of the soil exceeded the limit by $29.83 \%$ in average and after the addition of garden compost to the soil by $28.20 \%$. In the over-all period, the average values were decreased by $1.1 \%$. After the addition of garden compost into soil, the exceeded limit of Cd was lower (de O. Pinto et al., 2016; Khan et al., 2017; Urminská, 2017). The biocompatibility and high risk potential of $\mathrm{Cd}$ is influenced by $\mathrm{pH}$ and other chemical, physical and biological factors (Ying et al., 2018). We found that $\mathrm{pH} / \mathrm{KCl}$ in the monitored soil varied from 5.74 to 6.83 and soil with garden compost (relationship 1:1) from 6.78 to 7.98 . The $\mathrm{pH}$ is a key parameter in the assessment of mobility and bioavailability of risk elements in the environment (Makovníková et al., 2006). Uptake of Cd from soil into plants depends on the Cd contents in soil (Kabata Pendias, Pendias, 2011) and mobile bioavailable element forms. The most significant 
increase in the solubility of Cd occurs if $\mathrm{pH}$ of toxic $\mathrm{Cd}<6.5$ (Khun et al., 2008). Cd mobility and thus its bioavailability is highest in acidic soils with $\mathrm{pH}$ from 4.5 to 5.5 , although $\mathrm{Cd}$ in alkaline soils is mostly less mobile (He et al., 2015). Acidity in soil is very dangerous for organisms, - especially plant organisms. If $\mathrm{pH}$ level is higher than 7.5, mobility of Cd is influenced by solubility of $\mathrm{CdCO}_{3}$ or $\mathrm{Cd}_{3}\left(\mathrm{PO}_{4}\right)_{2}$ (Tlustoš et al., 2007). In this case, the mobility of toxic $\mathrm{Cd}$ is reduced. Our $\mathrm{pH}$ results showed that $\mathrm{pH}$ of the garden compost along with soil prevented the mobility of toxic Cd about $8.3 \%$ in average, at least partially too. Cd is highly toxic for all organisms (Tremlová et al., 2010; Mahurpawar, 2015; Rehman et al., 2017). According to Makovníková et al. (2006) and Tlustoš et al. (2007), the most commonly reported symptoms of Cd phytotoxicity are chlorosis of leaves, browning and root retardation, reduced photosynthetic activity, disruption of germination and plant transpiration, impairment of membrane systems, reddish-brown colouring of leaf veins, creation of purple-brown spots on leaves, necrosis of leaves and an overall decline in biomass due to leaf cast. If the growing agricultural crops are contaminated by $\mathrm{Cd}$; it can get into human body by ingestion. $\mathrm{Cd}$ is a nephrotoxic and hepatotoxic chemical element. Carcinogenic and teratogenic effects of Cd are also known (Bencko et al., 1995, Kafka, Punčochářová, 2002; Khun et al., 2008). We found that at present, it is ecologically and economically potentially suitable to use the compost for the needs of biodegradability of hazardous chemical elements and increase of soil fertility (Khan et al., 2017). Many research studies have found that Cd as a hazardous element exhibits intense mobility and bioavailability in relation to soil - plants - humans (Wang et al., 2015; Zhang et al., 2015; Shahid et al., 2017). The compost that was made variously is useful as a remediation medium too (Wu et al., 2016; Khan et al., 2017). Raw compost (from 2 to 6 months old) contains active microorganisms. It is not suitable to be immediately incorporated into the soil (maximum in autumn), because it must not cause damage to agriculture; it must be sufficiently mature. It can be used appropriately in soil mulching. Mature compost (from 6 to 12 months old), the application is suitable in a volume of $10-15 \mathrm{~kg}$ of garden compost from 1 to $2 \mathrm{~m}^{2}$ of soil to surface area. When planting, it is advisable to use compost mixed with 1:1 soil. For vegetables, the application rate is 5 litres per $1 \mathrm{~m}^{2}$ and for flowers approximately 3 litres per $1 \mathrm{~m}^{2}$ (Kmetová, 2013). The result was that garden compost as a remediation medium is available, easy to produce, inexpensive to the conditions that helped to achieved a decrease of toxic Cd contents potentially and its bioavailability.

\section{Conclusion}

Study of risk of heavy metals as an ecological pollutant in every part of the environment are still present-day. Cadmium is a top element for actual study, because it is a cumulative poison for all the organisms. Its negative impact on the cosystem of plants is manifested by reduced photosynthetic activity and interferes with the transformation of nitrogen compounds and is also reflected by the impaired membrane systems. Moreover, it operates as a retardant on the root system and causes chlorosis, even necrosis with an overall decline in biomass and yields. At present, it is important to reduce the accessibility of risk elements to ecosystems. Compost is such a remediation medium, which is practical, economical and affordable. It is very important to look for suitable and inexpensive remediation media to ecological prob- 
lems. Composting is an aerobic process, where biodegradable organic waste is converted to an organic-mineral fertilizer and a valuable remediation medium. The results showed that Cd contents in soil exceeded the maximum allowed limit of about $196 \%$. And decreased by $25 \%$ after adding compost. The $\mathrm{pH}$ prevented the mobility of $\mathrm{Cd}$ by about $8.3 \%$ on average. Interesting data was found regarding the relationship between Cd concentrations in soil and $\mathrm{pH} / \mathrm{KCl}$ in soil during the years and the relationship between Cd concentrations and $\mathrm{Cd}$ concentrations in soil affected by compost. Available Cd forms in soil were $53.3 \%$ and soil with compost were $45 \%$ on an average. The garden compost as a real remedial available and practical medium had reduced Cd contents.

Acknowledgements

This paper is supports by the projects KEGA 001SPU-4/2019 and KEGA 030SPU-4/2019.

\section{References}

Act No. 79/2015 Coll. (2015). The Waste Act (in Slovak). National Council of the Slovak Republic.

Antonkiewicz, J. \& Pełka R. (2014). Fractions of heavy metals in soil after the application of municipal sewage sludge, peat, and furnace ash. Soil Science Annual, 65(3), 118-125. DOI: 10.1515/ssa-2015-0003.

Belyuchenko, I.S. (2016). The role of complex compost in remediation of soils in cultivated lands. International Journal of Applied Environmental Sciences, 11(4), 1007-1023. http://www.ripublication.com

Benda Prokeinová, R. (2014). Statistic in the SAS system (in Slovak). Bratislava: ASPA Press.

Bencko, V., Cikrt, M. \& Lener J. (1995). Toxic metals in the living and working environment of the humans (in Slovak). Praha: Avicenum, Grada Publishing.

Borgulat, J., Mętrak, M., Staszewski, T., Wiłkomirski, B. \& Suska-Malawska M. (2018). Heavy metals accumulation in soil and plants of Polish Peat Bogs. Pol. J. Environ. Stud., 27(2), 537-544. DOI: 10.15244/pjoes/75823.

Boriová, K., Urík, M. \& Matúš P. (2015). Biosorption, bioaccumulation, biovolatilization of potentially toxic elements by microorganisms (in Czech). Chemické Listy, 109, 109-112.

Cuske, M., Karczewska, A., Gałka, B. \& Dradrach A. (2016). Some adverse effects of soil amendment with organic materials - the case of soils polluted by copper industry phytostabilized with red fescue. International Journal of Phytoremediation, 18(8), 839-846. DOI: 10.1080/15226514.2016.1146227.

Cuske, M., Karczewska, A. \& Gałka B. (2017). Speciation of Cu, Zn, and Pb in soil solutions extracted from strongly polluted soils treated with organic materials. Pol. J. Environ. Stud., 26(2), 567-575. DOI: 10.15244/pjoes/66710.

Das, K., Mandal, C., Ghosh, N., Banerjee, S., Dey, N. \& Adak M.K. (2014). Effects of exogenous spermidine on cell wall composition and carbohydrate metabolism of Marsilea plants under cadmium stress. Journal of Plant Physiology and Pathology, 2(3). DOI: 10.4172/2329-955X.1000127.

de O. Pinto, T., García, A.C., Guedes, J. do N., do A. Sobrinho, N.M.B., Tavares, O.C.H. \& Berbara R.L.L. (2016). Assessment of the use of natural materials for the remedy of Cd soil contamination. PLoS ONE, 11(6), e0157547. DOI: 10.1371 /journal.pone.0157547.

Decree of the MARD of Slovakia No. 59/2013 Coll. (2013). Section 27 of the Act No. 220/2004 Coll. The Protection and Use of Agricultural Land and on the Amendment (in Slovak), the Slovak Republic.

El Rasafi, T., Nouri, M., Said, B. \& Haddioui A. (2016). The effect of Cd, Zn and Fe on seed germination and early seedling growth of wheat and bean. Ekológia (Bratislava), 35(3), 213-223. DOI: 10.1515/eko-2016-0017.

Fazekaš, J., Fazekašová, D., Hrones, O., Benková, E. \& Boltižiar M. (2018). Contamination of soil and vegetation at a magnesite mining area in Jelšava Lubeník (Slovakia). Ekológia (Bratislava), 37(2), 101-111. DOI: 10.2478/eko-2018-0010.

Fazekašová, D., Boltižiar, M., Bobul’ovská, L., Kotorová, D., Hecl, J. \& Krnáčová Z. (2013). Development of soil parameters and changing landscape structure in conditions of cold mountain climate (case study Liptovská Teplička). Ekológia (Bratislava), 32(2), 197-210. DOI: 10.2478/eko-2013-0017.

Fiala, K., Kobza, J., Matúšková, L., Makovníková, J., Barančíková, G., Houšková, B., Pechová, B., Búrik, V., Brečková, V., Litavec, T., Chromaničová, A. \& Váradiová D. (1999). Binding soil analysis methods of the sub-monitoring system - Soil (in Slovak). Bratislava: VÚPaOP. 
He, S.Y., He, Z.L., Yang, X.E., Stoffella, P.J. \& Baligar V.C. (2015). Soil biogeochemistry, plant physiology, and phytoremediation of cadmium-contaminated soils. Adv. Agron., 134, 135-225. DOI: 10.1016/bs.agron.2015.06.005.

Kabata Pendias, A. \& Pendias H. (2011). Trace elements in soils and plants. London: CRC Press.

Kafka, Z. \& Punčochářová J. (2002). Toxicity of heavy metals in nature (in Czech). Chemické Listy, 96, 611-617.

Khan, M.A., Khan, S., Khana, A. \& Alam M. (2017). Soil contamination with cadmium, consequences and remedies using organic amendments. Sci. Total Environ., 601-602, 1591-1605. DOI: 10.1016/j.scitotenv.2017.06.030.

Khun, M., Ďurža, O., Milička, J. \& Dlapa P. (2008). Environmental geochemistry (in Slovak). Bratislava: Geo-grafika Press.

Kmetová, M. (2013). Composts and their impact on soil and crops (in Slovak). Naše Pole, 10, 24.

Liu, H., Li, L., Yin, CH. \& Shan B. (2008). Fraction distribution and risk assessment of heavy metals in sediments of Moshui Lake. J. Environ. Sci., 20(4), 390-397. DOI: 10.1016/S1001-0742(08)62069-0.

Liu, Ch., Zhou, P. \& Fang Y. (2016). Monitoring airborne heavy metal using mosses in the city of Xuzhou, China. Bull. Environ. Contamin. Toxicol., 96(5), 638-644. DOI: 10.1007/s00128-016-1777-8.

Mahurpawar, M. (2015). Effects of heavy metals on human health. International Journal of Research - Granthhaalayah, 1-7.

Makovníková, J., Barančíková, G., Dlapa, P. \& Dercová K. (2006). Inorganic contaminants in the soil ecosystem (in Czech). Chemické Listy, 100, 424-432.

Meharg, A.A., Norton, G., Deacon, C., Williams, P., Adomako, E.E., Price, A., Zhu, Y., Li, G., Zhao, F.J., McGrath, S., Villada, A., Sommella, A., De Silva, P.M., Brammer, H., Dasgupta, T. \& Islam M.R. (2013). Variation in rice cadmium related to human exposure. Environ. Sci. Technol., 47(11), 5613-5618. DOI: 10.1021/es400521h.

Morais, S., eCasta, F.G. \& Pereira M. de L. (2012). Heavy metals and human health. Open access peer - reviewed chapter: INTECH.

NAFC (2019). Partial monitoring system soil (in Slovak). Bratislava: VÚPaOP.

Onistratenko, N.V., Ivantsova, E.A., Denysov, A.A. \& Solodovnykov D.A. (2016). Heavy metals in suburban ecosystems of industrial centres and ways of their reduction. Ekológia (Bratislava), 35(3), 205-212. DOI: 10.1515/ eko-2016-0016.

Peng, Q., Chen, W., Wu, L. \& Bai L. (2017). The uptake, accumulation, and toxic effects of cadmium in Barnyardgrass (Echinochloa crus-galli). Pol. J. Environ. Stud., 26(2), 779-784. DOI: 10.15244/pjoes/65780.

Poláková, A., Šillerová, S., Drábová, B. Urminská, D. \& Szabová E. (2011). Copper, selenium supplemented yeast biomass - a source of microelements. Chemické Listy, 105, 1024

Rehman, Z.U., Khan, S., Brusseau, M.L. \& Shah M.T. (2017). Lead and cadmium contamination and exposure risk assessment via consumption of vegetables grown in agricultural soils of five-selected regions of Pakistan. Chemosphere, 168, 1589-1596. DOI: 10.1016/j.chemosphere.2016.11.152.

Shahid, M., Dumat, C., Khalid, S., Niazi, N.K. \& Antunes P.M.C. (2017). Cadmium bioavalability, uptake, toxicity and detoxification in soil-plant system. Rev. Environ. Contam. Toxicol., 241, 73-137. DOI: 10.1007/398_2016_8.

Shi-Wei, L., Hong-Jie, S., Hong-Bo, L., Jun, L. \& Ma L.Q. (2016). Assessment of cadmium bioaccessibility to predict its bioavailability in contaminated soils. Environment International, 94, 600-606. DOI: 10.1016/j.envint.2016.06.022

Stehlíková, B. (1999). Biometrics (Glossary of terms): textbooks for distance education and other forms of education (in Slovak). Nitra: SAU Press.

Šillerová, S., Drábová, B., Poláková, A. Urminská, D. \& Szabová E. (2011). Copper supplement yeast biomass as a source of nutrition microelements. Foodstuffs, 5, 84-87.

Šillerová, S., Drábová, B., Urminská, D., Poláková, A., Vollmannová, A. \& Harangozo L. (2012). Copper enriched yeast saccharomyces cerevisiae as a potential supplement in nutrition. Journal of Microbiology, Biotechnology and Food Sciences, 1(Special Issues), 696-702.

Šimanský, V. (2015). Changes in soil structure and soil organic matter due to different severities of fire. Ekológia (Bratislava), 34(3), 226-234). DOI: 10.1515/eko-2015-0022.

Tlustoš, P., Száková, J., Šichorová, K., Pavlíková, D. \& Balík J. (2007). Risks of metal in soil in agroecosystems in the Czech Republic (in Czech). Prague: VÚRV.

Tremlová, J., Száková, J. \& Tlustoš P. (2010). Evaluation of the possible influence of the risk elements contained in the soil on the human organism. Chemické Listy, 104, 349-352.

Urminská, D., Šillerová, S., Bojňanská, T. \& Chlebo P. (2013). Yeast saccharomyces cerevisiae as a source of zinc and magnesium and a potential supplement in nutrition. Ann. Nutr. Metab., 63(Suppl. 1), 543. DOI: $10.1159 / 000354245$. 
Urminská, J. (2017). Bioavailability of Cd influenced by selected remediation medium (in Slovak). Agrochémia, 21(57), 8-13.

Ying, H., Qianqian, CH. \& Meihua D. (2018). Heavy metals pollution and health risk assessment of soils in a typical peri-urban area in southern China. J. Environ. Manag., 207, 159-168. DOI: 10.1016/j.jenvman.2017.10.072.

Wang, L., Cui, X., Cheng, H., Chen, F., Wang, J., Zhao, X., Lin, CH. \& Pu X. (2015). A review of soil cadmium contamination in China including a health risk assessment. Environ. Sci. Pollut. Res., 22(21), 16441-16452. DOI: 10.1007/s11356-015-5273-1.

Wu, H., Lai, C., Zeng, G., Liang, J., Chen, J., Xu, J., Dai, J., Li, X, Liu, J., Chen, M., Lu, L., Hu, L. \& Wan J. (2016). The interactions of composting and biochar and their implications for soil amendment and pollution remediation: a review. Crit. Rev. Biotechnol., 37(6), 754-764. DOI: 10.1080/07388551.2016.1232696.

Ziehen, H. \& Brümmer G.W. (1991). Ermittlung der mobilität und Bindungsformen von chwermetallen in Boden mittels sequentielerxtractionen (in German). Mitteilungen Der Deutschen Gesellschaft, 66, 439-442.

Zhang, X., Chen, D., Zhong, T., Zhang, X., Cheng, M. \& Li X. (2015). Assessment of cadmium (Cd) concentration in arable soil in China. Environ. Sci. Pollut. Res., 22(7), 4932-4941. DOI: 10.1007/s11356-014-3892-6. 